\title{
Results of Thirty Years of Research on Corals and Reefs of Vietnam
}

\author{
Yuri Ya. Latypov \\ A.V. Zhirmunsky Institute of Marine Biology, Far East Branch, Russian Academy of Sciences, Vladivostok, Russia \\ Email: Itpv@mail.ru
}

Received 25 February 2016; accepted 16 April 2016; published 19 April 2016

Copyright (C 2016 by author and Scientific Research Publishing Inc.

This work is licensed under the Creative Commons Attribution International License (CC BY). http://creativecommons.org/licenses/by/4.0/

c) (i) Open Access

\begin{abstract}
The author traced the history of the thirty years of study of the Vietnamese reefs since the second half of the 20th century up to the present time. This paper describes the types of reefs, taxonomic composition and structure of Scleractinian reef ecosystems. It is shown that due to a high level of diverse knowledge revealed, high species richness of coral fauna of Vietnam (376 species of 80 genera) is a single point of origin coral fauna Indo-Pacific. Analysis of knowledge of Vietnamese corals and reefs revealed the extent of their positive or negative status under anthropogenic influence or under the level of wilderness protection, experiment on artificial cultivation of corals and the re-establishment of a coral community.
\end{abstract}

\section{Keywords}

\section{Scleractinia, Coral Communities, Species Richness, Vietnam}

\section{Introduction}

The development of fishery and aquaculture (abundance of fish, shrimp, lobster, fishing shellfish, pearl and seaweed) is connected with productivity of Vietnamese coastal waters and to a considerable degree, if not entirely, it is determined by studies of coral reefs and their state. The research on corals and reefs of Vietnam can be divided into three stages. The first research started with investigations of R. Sérene [1] on the basis of his expedition on "De Lanessan" board. He distinguished 64 species of scleractinian belonging to 33 genera. More complete list of scleractinian mostly from South Vietnam was set 15 years later by famous Russian natural scientist K. Dawydoff [2]. There were listed 210 species of scleractinian belonging to 51 genera. The first attempt at the analysis of hermatypic corals classification was made in Nhatrang bay by T.N. Loi [3] who had separated 4 typical facies with dominant genera for some insular reefs and reefs located on capes and also created the list of scleractinian that included 78 species from 38 genera. These investigators established species compo- 
sition of scleractinian that could be compared with species composition of corals in Australia and Indonesia.

The systematic detailed researches on Vietnamese corals and reefs were conducted in the period from 1980 to 1995 in expeditions of Marine Biology Institute of the Far Eastern Branch of the Russian Academy of Sciences in cooperation with Institute of Oceanography (Nhatrang), Institute of Marine Environment and Resources (Haiphong), Vietnam Academy of Science and Technology and World Wide Fund for Nature, [3]-[14]. The majority of researches were dedicated to the research on the composition and classification of scleractinian. The data on widening the research region, abundance and diversity of scleractinian were summarized and acquired. Some publications reviewed the dispersal and abundance of mass species of macrophytes and macrobenthos accompanied corals. Some cases investigated reef communities altogether [11]. Participating in joint marine and terrestrial expeditions Vietnamese specialists significantly improved their research level. Lang Van Ken, Vo Shi Tuan, and Nguyen Hui Yet quite self dependently and productively investigated reefs [15]-[20]. But some part of received results is still in unpublished reports; other results were published only in regional collections, difficult of access; some of them appeared only in Vietnamese publications.

Since the beginning of this century all reef-building zones of Vietnam from north line of Gulf of Tonkin to south line of Gulf of Siam and Spartly islands in the South China Sea (their country affiliation is still a disputable theme) including all any large islands and banks were investigated [21]-[38]. All types of reefs and more than 350 species of reef-building corals were monographic ally described; their field guides were published [26] [29] [33] [35]. The demand arose for summarizing all volume of information received about the coral composition and classification, specifics about reef formation in Vietnam and their connection with Indo-Pacific reef ecosystem. Fast growth of 70 million population of this country, increasing touristic interest in its coral reefs, and intensification of aquaculture business [31] [39] are the reasons of rising stress for this unique ecosystem.

Holistic view on composition and structure of coral communities and conditions for Vietnamese reefs permits evaluating the level of their degradation, possibilities for preservation and reconstruction. Also it allows experimenting with coral artificial rearing and renewal their communities.

\section{Results and Discussion}

With the application of autonomous diving equipment since 1980 the coral communities were investigated in 125 transects of 70 reefs in 13 zones (Figure 1 ).

Quarter-century after 22 transects of seven reefs were studied again. The composition and structure of taxonomic population of scleractinian of Vietnamese reef ecosystem were revealed. 376 species of reef-building scleractinian from 80 genera were determinate, 169 species from 33 genera were not previously known in Vietnam, and 16 species of 6 genera were described for science for the first time. Scleractinian species richness is based on 7 genera: Acropora-62 species, Montipora-29, Porites-22, Favia-15, Turbinaria-11, Pavona10, they are $39.62 \%$ of all reef-building corals diversity (Figure 2, Table 1). Dozens of communities, bionomical zones and facies formatted by combination of particular species of macrophytes, scleractinian, alcyonarian, bivalve mollusks and sea urchins that characterize the ecosystem of Vietnamese reefs at large were identified and described. The most common communities were the communities of sea weed Sargassum japonicum $+S$. polycystum, Laurencia papilosa + Acropora cytherea, corals Acropora cytherea + Montipora aequituberculata, alcyonarian Sarcophyton trocheliophorum + Lobophytum pauciflorum, shellfishes and gorgonians Malleus malleus + Juncella fragilis, spatangoid sea urchins Metalis sternalis + Brissus latecarinatus, Brissus latecarinatus + Heteropsammia cochlea [4] [8] [27] [34] [40].

Coral reefs of Vietnam are related to epicontinental monsoon type [2] [4] [5] [41] [42]. They are located at peripherical part of the South China Sea, and its shallow water is highly eutrophicated and filled with mud because of large number of terrigenous materials brought. Other hydrological conditions also differ from optimal conditions for reef-building corals [25]. During south-west monsoons approximately 5 - 10 typhoons with the strongest hurricane wave's fall on Vietnamese coast [31] [36] [43]. All these factors have a significant impact on characteristics of formation of reefs that generally take place on rocky, rock-ribbed and less often on organogenic understratum.

Reef-building corals of Vietnam form various reef structures. They can be small fringing reefs that border inland and island coasts, platform reefs (Bach Long Vi island), barrier reef (Ly Son island and Jiang Bo reef) and atolls (Spartly islands) in open part of the South China Sea [15] [18] [44]. Vo Shi Tuan and Hodgson [36] think that true reef framework and coral gardens develop in Vietnam. The uniqueness of geomorphological and cli- 
matic conditions is the factor that clearly divides Vietnamese adjoining reefs in two types: structural and structureless in accordance with Wainwright [45] or cortex defined by Latypov [11], Figure 3. Structural reefs

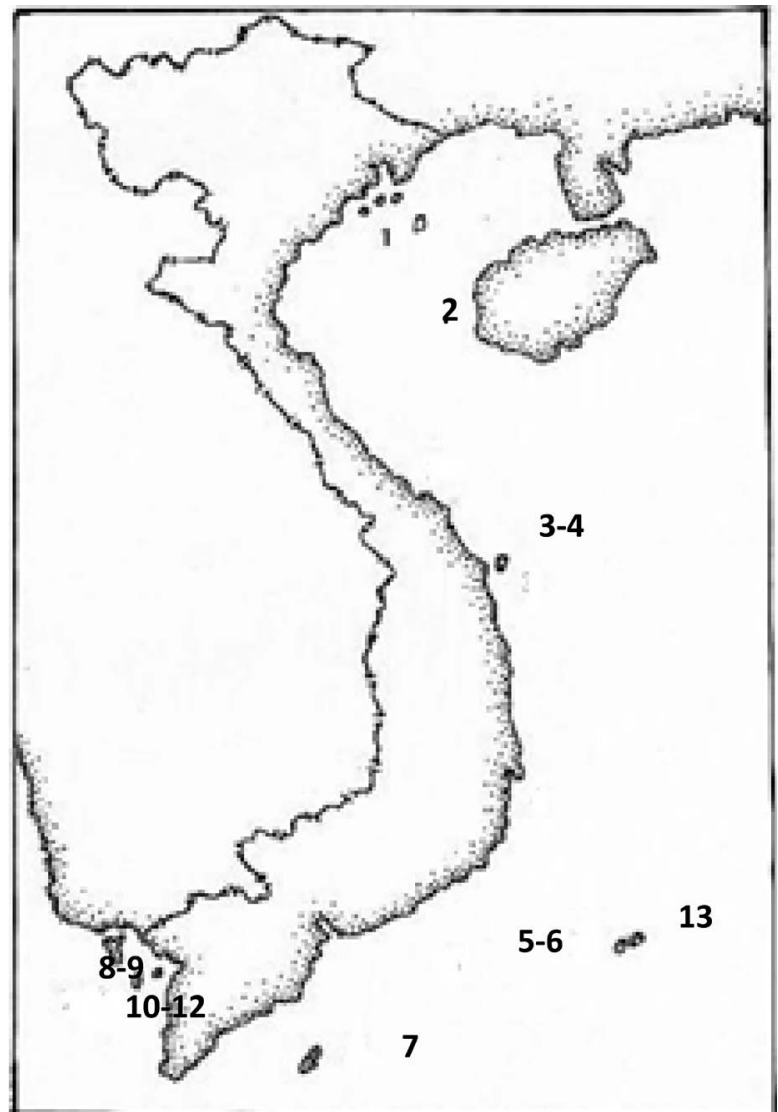

Figure 1. The main research areas of the reef. 1-Baitylong archipelago, 2-Bat Long Vi Island, 3-4-Central Vietnam (4/7), 5-6-Katuik and Ngũ Phung islands (2/4), banks of Astrolâband Royal Bishob, 7-Con Dao islands (1/3), 8-9Islands Anthoj, 10-12-Islands Namsu, Thochu et al., (2/8), 13-Spratly Islands. In parentheses in denominator-the number of reefs and transects studied again.

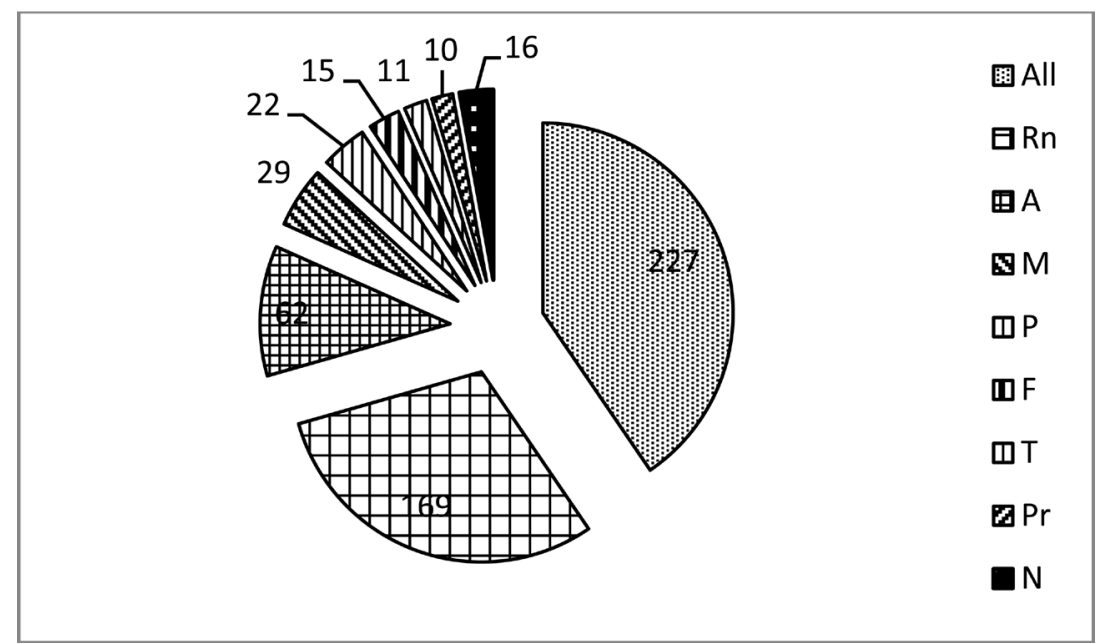

Figure 2. Distribution of taxonomic composition scleractinian. All-the main species composition, $\mathrm{N}-$ no known for science, A-species Acropora, M-Montipora, F-Favia, P-Pavona, Pr-Porites, T-Turbinaria, Rn-species not previously known for Vietnam. Digit-number of species. 
Table 1. Taxonomic composition of scleractinian.

\begin{tabular}{|c|c|c|}
\hline Genera species & Genera species & Genera species \\
\hline Acantastrea 4 & Euphyllia 6 & Micedium 1 \\
\hline Acropora 62 & Favia 15 & Oulastrea 2 \\
\hline Alveopora 3 & Favites 9 & Oulophyllia 3 \\
\hline Anacropora 1 & Fungia 12 & Oxypora 2 \\
\hline Astreopora 6 & Galaxea 4 & Pachyseris 4 \\
\hline Australogyra 1 & Gardinoseris 2 & Palauastrea 1 \\
\hline Balanophyllia 2 & Goniastrea 7 & Pavona 10 \\
\hline Barabattoia 2 & Goniopora 8 & Pectinia 3 \\
\hline Caulastrea 2 & Halomitra 1 & Physogyra 1 \\
\hline Celoseris 1 & Helophugia 1 & Platygyra 4 \\
\hline Coscinarea 3 & Herpolitha 2 & Plerogyra 1 \\
\hline Ctenactis 1 & Heterocyathus 2 & Plesiastrea 1 \\
\hline Cycloseris 8 & Hetrepsammia 2 & Pleuractis 2 \\
\hline Cynarina 1 & Hydnophora 3 & Pocillopora 7 \\
\hline Cephastrea 4 & Isopora 2 & Podobacia 2 \\
\hline Dendrophyllia 8 & Leptastrea 4 & Polyphyllia 2 \\
\hline Diaseris 1 & Leptorya 1 & Scolymia 2 \\
\hline Diploastrea 1 & Leptoseris 7 & Seriatopora 2 \\
\hline Echinophyllia 5 & Lythophyllon 4 & Stylocoeniella 1 \\
\hline Porites 22 & Lobophyllia 7 & Stylophora 2 \\
\hline Psammocora 7 & Madracis 1 & Symphyllia 6 \\
\hline Pseudosiderastrea 1 & Merulina 2 & Trachyphyllia 1 \\
\hline Sandalolitha 2 & Montasrea 5 & Tubastrea 4 \\
\hline Ehinopora 3 & $\begin{array}{c}\text { Montipora } 29 \\
\text { Moseleya } 1\end{array}$ & Turbinaria 11 \\
\hline
\end{tabular}

of Vietnam mainly form in closed bays and on the organogenic sediments of Holocene reefs [4] [41]. Structureless reefs for the most part form on capes and open bays primarily on rocky and stony understratum [4] [10] [11] [17] [18]. Great morphological diversity of island reefs in large shallow bays is the most peculiar to Vietnam. Gulf of Tonkin and Gulf of Siam are located in the north and in the south of Vietnam. On the one hand they are really different from geographical point of view, but on the other hand they are knit together by shallowness and high eutrophication of waters. The best known reefs of both gulfs with relatively high degree of similarity in composition and structure of communities are notable for their unique features [23] [24] [30] [32] [35] [46].

From the beginning of $80 \mathrm{~s}$ of the previous Century there were only researches on the composition and distribution of scleractinian during 10 - 15 years. There was a visible progress in growth dynamics of corals taxonomic diversity as the geography and numbers of studied corals were growing (Figure 4, Table 2). It was found that coral fauna with its high species diversity is associated with the one of Australia, Indonesia and Philippines and it is included in Malay-Indonesian fertile center of coral origin of Indo-Pacific region [25] [27] [30] [47].

With organization of long-term naval expeditions in the perspective of reef ecosystem research the purposes were concretized and research tasks were expanded. Reef communities started to be under more purposed and detailed investigation, the analysis of their similarities and differences in the same neighbors and in geographically outlying regions had started.

All types of Vietnamese reefs have similar biogeomorphological profiles. Bottom topography, deepness, wave and stream actions, light, temperature and sedimentation of suspended material, all these factors participate in the creation of indicative horizontal and vertical zonality, in spreading of corals, seaweed and other organisms. Whereas zonality in structural and structureless reefs varies with location and reef type, the main zones peculiar to the majority of reefs can be typified. Lagoon, reef flat, reef peak and reef slope are all about structural reefs in offshore. Backreef, terrace, reef rim or reef side and reef slope are of structureless reefs. But bionomical zonality in species composition, coral forms of life and coralobiont coexist complex is clearly visible in all researched reefs [5]-[9] [22] [48].

The communities of monospecific colonies in lagoons and reef slopes that entirely cover the understratum surface for many hundreds of meters (types of species Acropora, Montipora, branchy Porites, Galaxea); communities of reef slopes with the highest biological diversity of all reef population; monospecific communities of alcyonarian with high biomass on to $45,920 \mathrm{~g} / \mathrm{m}^{2}$ are formed on the majority of reefs [8] [27]. 


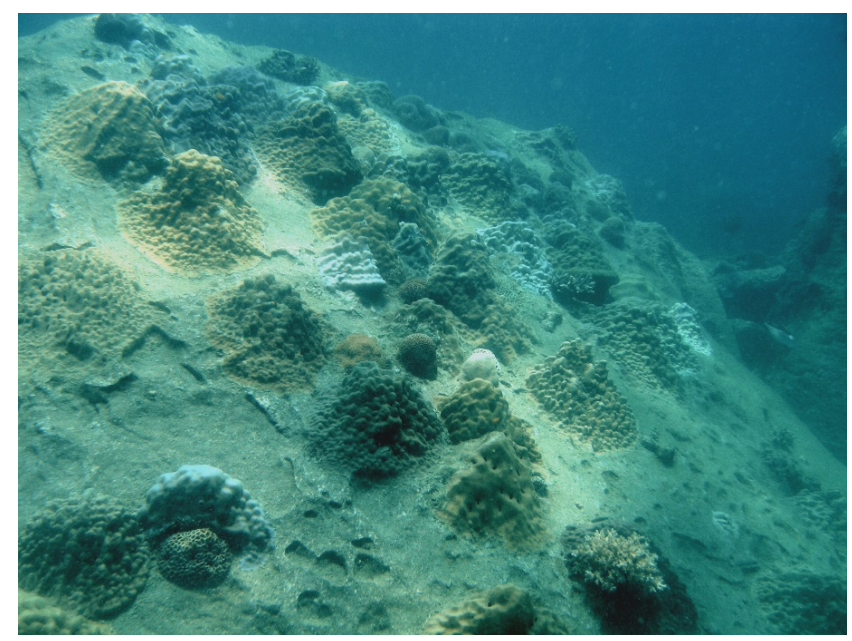

(a)

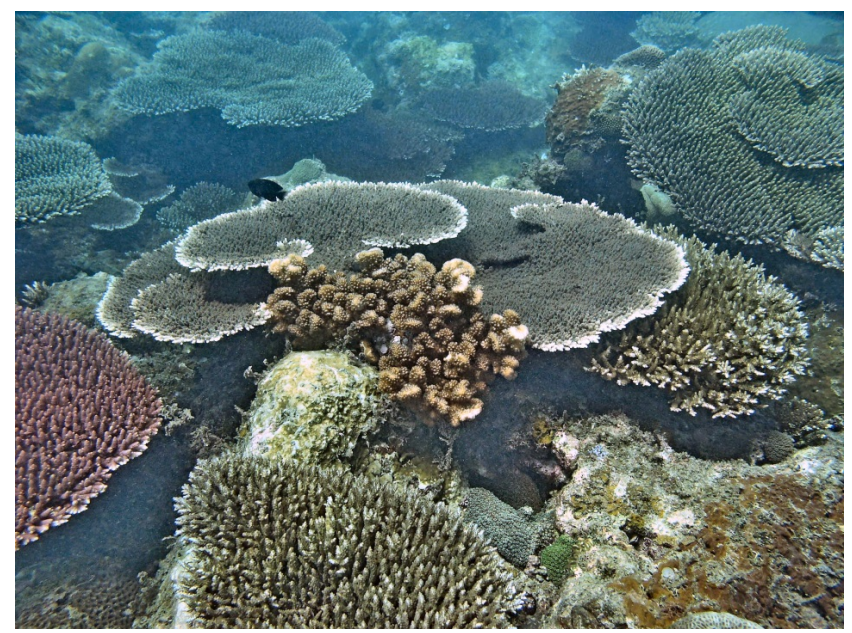

(b)

Figure 3. Types of reef-structureless (a) with spotty crust coating corals, reef Con Den, depth $7 \mathrm{~m}$ and structural (b) with multi-level solid coating, reef Con Dao, depth $4 \mathrm{~m}$.

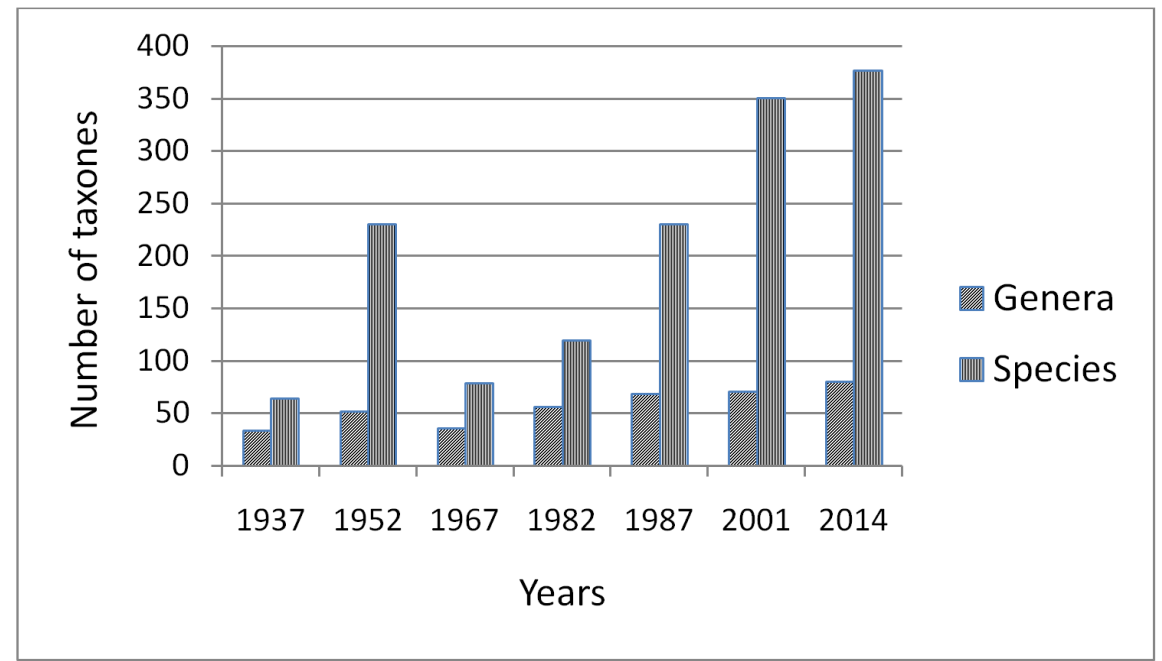

Figure 4. Dynamics of growth of the axis taxa of corals. 
Table 2. Species richness of scleractinian on reef different areas.

\begin{tabular}{ccccccc}
\hline Area & Number & Number of & Number of & & \multicolumn{3}{c}{ Number of common species } \\
\cline { 5 - 7 } & of reefs & transects & species & I & Ph & Au \\
\hline Tonkin Gulf & 14 & 17 & 190 & 160 & 166 & 138 \\
Central Vietnam & 4 & 6 & 219 & 132 & 122 & 98 \\
Ly Son Island & 2 & 4 & 166 & 156 & 159 & 137 \\
Khanh Hoa Province & 18 & 41 & 265 & 176 & 185 & 159 \\
Ngu Phung, Katuik Islands & 4 & 6 & 222 & 176 & 183 & 150 \\
Con Dao Islands & 5 & 10 & 204 & 173 & 180 & 147 \\
Thochu Island & 2 & 4 & 186 & 171 & 172 & 142 \\
Namsu Islands & 4 & 8 & 147 & 121 & 131 & 101 \\
Anthoi Islands & 6 & 8 & 140 & 127 & 127 & 97 \\
Spratly Islands & 5 & 10 & 261 & 184 & 148 & 152 \\
Vietnam & 70 & 125 & 376 & $76.4 \%$ & $81.6 \%$ & $86.6 \%$ \\
\hline
\end{tabular}

I—Indonesia, $\mathrm{Ph}$ —Philippine, $\mathrm{Au}$-Australia.

Central Vietnam and Gulf of Tonkin and Gulf of Siam reefs have some special aspects. Due to the excessive eutrophication and shallowness in these regions branchy Acropora and encrusted Montipora were substituted for massive Porites and various alcyonarian in some reefs, they became predominant [23]-[35].

Communities of Bach Long Vi island platform reef stand apart; they clearly demonstrate obvious axial zonality. The central part of reef (reef flat) is marked by homogeneous coral community with majority of branchy and laminar colonies of Acropora and Montipora creating wide fields. Various large bioherms form on the slopes and steep-bottom parts of reef (Figure 5). Peripheral tableland of reef consists of wide zone of coral genetic detritus, sand and oozes [28] [31]. Reef community in the Bach Long Vi island comes close to the late development stage as similar communities on the reefs of Indo-Pacific ecosystem [40] [49]-[51].

Many repeated researches on some reefs in Khanh Hoa province, Gulf of Siam, Thu and Con Dao islands permitted to find out the level of reef change ability and stability according to the anthropogenic pressure, protect ability and farness of human settlements.

For example, reefs in the Nha Trang bay, Khanh Hoa province moved far away from each other not more than 10 kilometers are marked by widely different states. Mieu reef only two kilometers away from the city is under extreme anthropogenic pressure. It is surrounded by dozens of aquaculture farms; there is permanent construction and fitting of living communities and beaches for tourists in its coast line. All drugs and chemicals from aquaculture floats and ground of construction process are streamed. One-time prosperous reef in the south and south-east practically had been dying during last 5 years, and now its population is only about macrophytes spots and some dozens of declining reef colonies [26] [32] [35] [43]. Widening of living communities and daily seafood harvesting with up-to-date techniques happen in the island along coast of Gulf of Siam. The high signature of coral quantity and variability reduction and reduction of their coralobiont coexist complexes were marked out. Species richness reduced in 2.5 times, the coverage of understratum with corals came down to $40 \%-20 \%$ [32] [52]. At the same time reefs guarded by reservation conditions and located 10 - 20 kilometers far from Nha Trang city and port are in the optimal conditions even with daily tourist excursions (Mun Island) and dozens of divers among them. Also reefs located in inaccessible places due to their farness (Bach Long Vi, Spartly islands) or complete defense lands (east reefs of Con Dao islands, Figure 3(b)) are in almost perfect condition of both corals and reef communities in whole [31] [35].

Analysis of abiotic conditions, rat of growth, regeneration process and rate of corals permitted to hold the set of experiments in their artificial rearing. Four summer researches on rearing of more than 100 coral fragments of 14 species from 4 genera in different reefs of Khanh Hoa province were hold. Obtained results showed that fragments survival rate was $100 \%-86 \%$. All survived fragments had rehabilitated to standard colonies with increased number of branches and overall size of colony as many as $210 \%-275 \%$. Two years after the moment of coral fragment transfer in the artificial installations the formation of new coral community became possible 


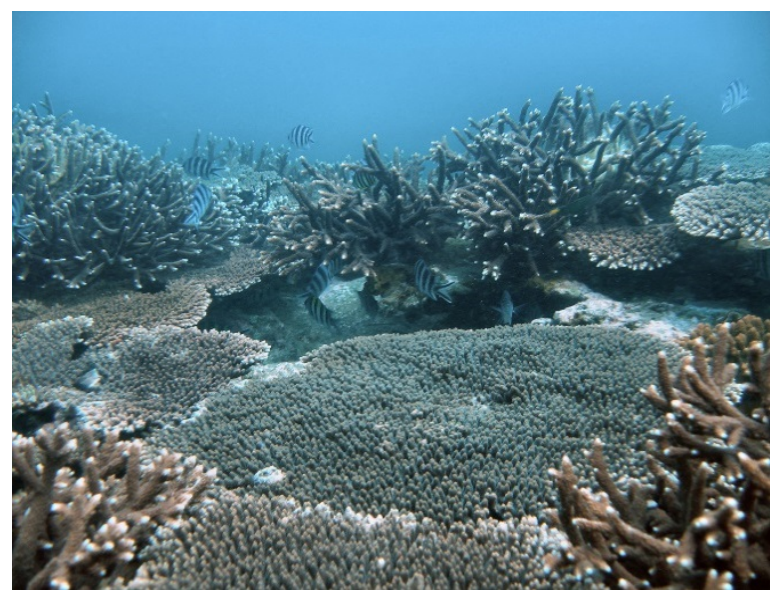

(a)

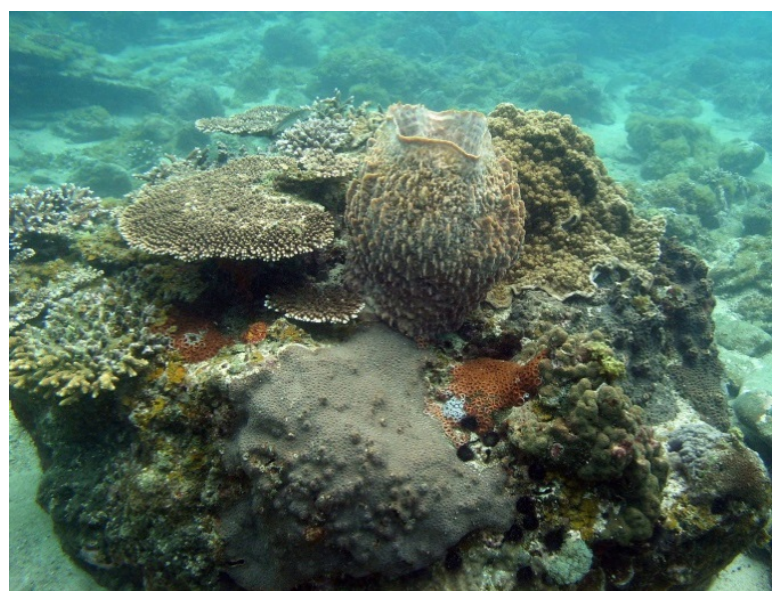

(b)

Figure 5. The community of Acropora (a) and bioherms (b) on the reef Bat Long Vi, depth of 4 and $6 \mathrm{~m}$.

with pearl weed, ascidians, mussels, damselfishes (Pomacentridae), and usual residents of natural colonies of Acropora with common to them homing to chosen coral [34] [53].

Frequent typhoons and hurricanes attacking the Vietnamese coast heavily damage both country and its reefs. Typhoons have a significant effect on coral reefs up to their full extermination. With the influence of typhoons the morphology of reef body, composition and structure of coral community are affected too [43] [54] [55]. In the coastal area reefs are also sprinkled over with heavy layer of ground carried away from paddy fields and waterlogged rivers. But continuous reef visiting has allowed establishing that 3 - 4 years after coral community restores on the partially broken reef due to vegetative reproduction of survival corals and gain of larva form neighboring survivor coral banks. In seven years the proliferative colony of recently landed scleractinian Platygyra daedalea was found out on the wrack reef. This coral does not have to find the other half for breeding because its colony produces both egg and sperm cells. Its larva settles during metamorphosis as late as 3 - 4 days after the fertilization, but without substratum planula preserves the capacity for settlement during three months [32] [43] [54]-[56].

\section{Conclusion}

In total 360 - 410 species of reef-building scleractinian from 70 - 80 genera are registered on the reefs of Indonesia, Philippines and Great Barrier Reef of Australia [47]. This west region of Pacific Ocean is considered as the center of tropical coral fauna origin. The maximum coral diversity is presented in what is referred to as fertile origin center of coral triangle with corners in Philippines, Malay Peninsula and New Guinea [30] [47] [57] [58]. Fauna of Vietnamese scleractinian which contains 376 species from 80 genera is classified as a part of this fertile triangle. All coast line of Vietnam from Gulf of Tonkin to Gulf of Siam is the unified whole geographically, and it is a part of Indo-Polynesian province of Indo-Pacific region [25] [30] [33].

\section{Acknowledgements}

Exploring the reefs would be impossible without the full commitment and support, including financial directorates, Institute of Marine Biology FEB RAS, Institute of Oceanography and Marine Institute Environment and Resources (Nha Trang and Haiphong, Vietnam), G. Soros Foundation. Author sincerely grateful academician A.V. Zhirmunsky, professors Nguyen Tac An, Nguyen Chu Hoy, my fellow V.A. Brykov, I.N. Budin, A.G. Goloseev, Nguyen Huy Dinh, Lang Van Ken, A.N. Malyutin, Yu.P. Popov, N.I. Selin, N.K. Christoforova. for friendly assistance in the conduct of research.

\section{References}

[1] Sérene, R. (1937) Inventaires des invertebres marine de l’Indochine. Institute of Oceanography Indochina, 30, 3-83.

[2] Dawydoff, C. (1952) Contribution et l'etude des invertebres de la faune marine benthique de l'Indochina. Bulletin 
Biologique de la France et de la Belgique, 37, 1-158.

[3] Loi, T.N. (1967) Peuplementsanimauxetvegetaux du substrat des intertidal de la Baie de Nha Trang (Vietnam). Memory Institute of Oceanography, 11, 1-236.

[4] Latypov, Yu.Ya. (1982) Species Composition and Distribution of Scleractinians in Reefs of the Khanh Hoa Province (South Vietnam). Biologia Morya, 6, 5-12.

[5] Latypov, Yu.Ya. (1987) Species Composition and Distribution of Scleractinian in Islands Socotra. Biologiamorya, 4. 35-41.

[6] Latypov, Yu.Ya. (1988) Reefs and Communities of Scleractinian of Islands Thu (South China Sea). In: Biology of Coastal Waters of Vietnam: Hydrobiological Researches Littoral and Sublittoral Southern Vietnam, FEB AN USSR, Vladivostok, 111-119. (In Russian)

[7] Latypov, Yu.Ya. (1992) Reefs and Communities of Scleractinians in the Western Part of the Bai Thu Long Archipelago (South China Sea). Biologia Morya, 1-2, 17-26.

[8] Latypov, Yu.Ya. (1994) Benthic Communities of the Corals Reef of the Kondao Islands in the South China Sea. Russian Journal of Marine Biology, 20, 136-143.

[9] Ken, L.V. (1991) The Stony Corals in the Sea of Vietnam. Mar. Environ. and Res. (1986-1990). Scientific and Technic Publishing House, Hanoi, 127-135.

[10] Latypov, Yu.Ya. (1986) Coral Communities of the Namsu Islands (Gulf of Siam, South China Sea). Marine Ecology Progress Series, 29, 261-270. http://dx.doi.org/10.3354/meps029261

[11] Latypov, Yu.Ya. (1995) Community Structure of Scleractinian Reefs in the Baitylong Archipelago (South China Sea). Asian Marine Biology, 12, 27-37.

[12] Yet, N.H. (1991) Some Data on Reef-Building Corals in Song Tu Island Group of Spratly Archipelago. Mar. Rres. Environ. Sci. Techn. Publ. House, Hanoi, 135-143. (In Vietnamese)

[13] WWF Vietnam Marine Conservation Southern Survey Team (1993) Survey Report on the Biodiversity Resourse Utilization and Conservation Potential of Hon Mun, Cat Ba Region, Haiphong, N. Vietnam. Gland, Switzerland. Unpublished Report, 63 p.

[14] WWF Vietnam Marine Conservation Southern Survey Team (1994) Survey Report on the Biodiversity Resourse Utilization and Conservation Potential of Coto Islands, Quangninh Province, N. Vietnam. Gland, Switzerland. Unpublished Report, 79 p.

[15] Ken, L.V. (1991) Stony Corals and the Coral Reefs of Catba Islands. Marine Environment and Resources. Hanoi. Sci. Tech. Publ. House, 144-151.

[16] Yet, N.H. (1989) Research Results of Corals and Coral Reefs in Western Tonkin Gulf. Tay Nguen Va Moy Truong Bien, 6, 35-36.

[17] Yet, N.H. (1997) Thánmphánloàihôcúngvàcáutrúc ran san hôĐàoThuyênChài (QuânĐâoTruòngSa). Tai nguyênvàmôitruongbiên. Hanoi. IV, 299-313.

[18] Ken, L.V. (1996) San hócúng (Scleractinia) vàrąn san hôquanhdảo Bach Long Vi. Tàinguyênvêmôitruòngbiền, III, 308-319.

[19] Ken, L.V. and Yet, N.H. (1996) The Species Composition of Hard Corals and Structure of Coral Reefs in Nam Yet Island of Spratly Archipelago. "Resources and Environment” V. III, “Sci\&Techn.” Publ. House, Hanoi, III, 288-297. (In Vietnamese)

[20] Latypov, Yu.Ya. (2000) Macrobenthos Communities of Coral Reefs of the An Thoi Archipelago, South China Sea. Biologiya Morya, 26, 22-30.

[21] Latypov, Y.Y. (2001) Coral Communities of Reefs of Central Viet Nam. Biologiya Morya, 27, 238-241.

[22] Vo, S.T. and Nguyen, H.Y. (1995) Coral Reefs and Reef Building Corals of Vietnam. Collection of Marine Research Works, 6, 101-110.

[23] Latypov, Y.Y. (2003) Reef-Building Corals and Reefs of Vietnam: 1. The Gulf of Thailand. Russian Journal of Marine Biology, 29, S22-S33.

[24] Latypov, Y.Y. (2003) Reef-Building Corals and Reefs of Vietnam: 2. The Gulf of Tonkin. Russian Journal of Marine Biology, 29, S34-S45.

[25] Latypov, Y.Y. (2005) Reef-Building Corals of Vietnam as a Part of the Indo-Pacific Reef Ecosystem. Russian Journal of Marine Biology, 31, S34-S40. http://dx.doi.org/10.1007/s11179-006-0013-5

[26] Latypov, Y.Y. (2008) The Common Coral of Vietnam: Field Handbook. Far Eastern National University Press, Vladivostok, 148p.

[27] Latypov, Y.Y. (2007) Coral Reefs of Vietnam. Nauka, Moscow, 179c. (In Russian) 
[28] Latypov, Y.Y. (2008) Species Composition and Structure of Coral Community of a Platform Reef at Bach Long Vi Island in the South China Sea. Russian Journal of Marine Biology, 34, 249-253. http://dx.doi.org/10.1134/S1063074008040068

[29] Latypov, Y.Y. and Long, P.Q. (2010) The Common Hard Corals of Vietnam. Ministry of Agriculture and Rural Development, Hanoi, 281 p.

[30] Latypov, Y.Y. (2011) Scleractinian Corals and Reefs of Vietnam as a Part of the Pacific Reef Ecosystem. Open Journal of Marine Science, 1, 50-68.

[31] Latypov, Y.Y. (2013) Barrier and Platform Reefs of the Vietnamese Coast of the South China Sea. International Journal of Marine Science, 3, 23-32.

[32] Latypov, Y.Y. (2014) Species Composition and Distribution of Scleractinian on Reefs of Wan Phong and Nha Trang Bays (South Vietnam). International Journal of Advanced Research in Biological Sciences, 1, 1-14.

[33] Latypov, Y.Y. (2014) Scleractinian Corals of Vietnam. Science Publishing Group, pp. I-XXXIV, 1-481.

[34] Latypov, Y.Y. (2014) Artificial Cultivation of Hermatypic Corals on Experimental Frame on the Reefs of Vietnam. Journal of Biodiversity, Bioprospecting and Development, 1, 1-6.

[35] Latypov, Y.Y. (2015) The Spatial-Temporal Variability and Stability of Vietnamese Reef Communities. Russian Journal of Marine Biology, 41, 103-110. http://dx.doi.org/10.1134/S1063074015020066

[36] Vo, S.T. and Hodgson, G. (1997) Coral Reefs of Vietnam: Recruitment Limitation and Physical Forcing. Proceedings of the 8th International Coral Reef Symposium, 1, 477-482.

[37] Vo, S.T., Yet, N.H. and Alino, P.M. (1997) Coral and Coral Reefs in the North of Spratly Archipelago-The Results of RP-VN JOMSRE-SCS 1996. Proceeding of Scientific Conference on Philippines-Vietnam, Hanoi, 22-23 April 1996, 87-101.

[38] Yet, N.H. and Ken, L.V. (1997) Characteristics of Scleractinian Communities in the Son Tra Island (ThuaThien-Hue Province). Tài Nguyên và Môi Truò̀ng Biển, 4, 314-327.

[39] Cheung, C. (1994) Vietnam Marine Conservation. Coastal Management in Tropical Asia, 4, 21-23.

[40] Latypov, Y.Y. (1999) Benthic Communities of Coral Reefs of Tho Chu Island, Bay of Thailand, South China Sea. Biologiya Morya, 25, 201-208.

[41] Preobrazhensky, B.V. (1986) Sovremennye Rify. Nauka, Moscow, 244 p.

[42] Sorokin, Y.I. (1990) Coral Reefs Ecosystems. Nauka, Moskow, 503 p.

[43] Latypov, Y.Y. and Selin, N.I. (2012) Changes of Reef Community near Ku Lao Cham Islands (South China Sea) after Sangshen Typhoon. American Journal of Climate Change, 1, 41-47. http://dx.doi.org/10.4236/ajcc.2012.11004

[44] Latypov, Y.Y. (1990) Korallyskleraktinii V'etnama. Tamnasteriidy, Astrotseniidy, Potsilloporidy, Dendrofilliidy [Scleractinian Corals of Vietnam. Thamnasteriidae, Astroceniidae, Pocilloporidae, Dendrophylliidae]. Nauka, Moscow, 80 p. (In Russian)

[45] Wainwright, S.A. (1965) Reef Communities Visited by the Israel South Red Expedition, 1962. Bulletin of Sea Fish Station Israel, 8, 40-53.

[46] Yet, N.H. and Ken, L.V. (1996) Some Data on Species Composition and Distribution of Scleractinian Corals in Ha Long Bay. Journal of Biology, 18, 7-13.

[47] Veron, J.E.N. (1995) Corals in Space and Time: The Biogeography and Evolution of the Scleractinia. Australian Institute of Marine Science, $321 \mathrm{p}$.

[48] Dautova, T.N., Latypov, Y.Y. and Dautov, S.S. (1999) Composition and Structure of the Coral Communities of the Bai Ty Long Archipelago under Different Ecological Conditions. Russian Journal of Marine Biology, 25, 106-107.

[49] Pichon, M. (1981) Dynamic Aspects of Coral Reef Benthic Structures and Zonation. Proceedings of the 4th International Coral Reef Symposium, 1, 581-594.

[50] Dollar, S. (1982) Wave Stress and Coral Community Structure in Hawaii. Coral Reefs, 1, 71-81. http://dx.doi.org/10.1007/BF00301688

[51] Dai, C.F. (1996) Dynamics of Coral Communities. Biodiversity and the Dynamics of Ecosystems, DIWPA Series, 1, 247-265.

[52] Latypov, Y.Y. and Selin, N.I. (2013) Some Data on Spatio-Temporal Stability and Variability of Coral Reefs in Khanh Hoa Province (Vietnam). Environment, Ecology \& Management, 2, 1-16.

[53] Latypov, Y.Y., Ly, B.M.L., Hoang, H., Long, P.Q. and Kho, N.B. (2013) Experimental Artificial Cultivation of Corals from Colony Fragments. Russian Journal of Marine Biology, 39, 148-152. http://dx.doi.org/10.1134/S1063074013020053

[54] Harmelin-Vivien, L.M. (1994) The Effects of Storms and Cyclones on Coral Reefs: A Review. Journal of Coastal Re- 
search, 12, 211-231.

[55] Harmelin-Vivien, L.M. and Laboute, P. (1986) Catastrophic Impact of Hurricanes on Atoll Outer Reef Slopes in the Tuamotu (French Polynesia). Coral Reefs, 5, 55-62. http://dx.doi.org/10.1007/BF00270353

[56] Nozawa, Y. and Harrison, P.L. (2000) Larval Settlement Patterns, Dispersal Potential, and the Effect of Temperature on Settlement of Larvae of the Reef Coral, Platygyra daedalea, from the Great Barrier Reef. Proceedings of the 9th International Coral Reef Symposium, 1, 23-27.

[57] Eckman, S. (1953) Zoogeography of the Sea. Sidgwick and Jackson, London, 417 p.

[58] Stehli, E.G. and Wells, I.W. (1971) Diversity and Age Patterns in Hermatypic Corals. Systematic Zoology, 20, 115-126. http://dx.doi.org/10.2307/2412052 